\title{
THE POWER OF SAVING WISDOM ${ }^{1}$
}

\section{Cornelis Bennema}

Salvation is one of the most fundamental concepts of the Christian faith. Questions such as 'What is salvation?', 'How does one enter into salvation?' and 'How does one stay in salvation?' must be answered adequately in order to understand the Christian faith. To these important questions a further one is added, namely, 'What is the role of the Spirit in all this?' This thesis examines the Fourth Gospel to address these questions and looks especially at the concept of W/wisdom (wisdom being that what personified Wisdom possesses or gives) because this concept is found to be significant in explaining the relationship between Spirit and salvation.

Chapter 1 surveys the contribution of contemporary Johannine scholarship to our questions, and the major players are Bultmann, Porsch, Loader and Turner (but also Forestell and Hamid-Khani). It is concluded that a more complete model of Johannine soteriology is missing, that Johannine scholarship has not adequately explored the soteriological functions of the Spirit (in relation to W/wisdom), and that it is necessary to examine the extent to which the Jewish wisdom traditions may function as a possible background for the relationship between John's pneumatology and soteriology. Hence, the aim of the thesis is to elucidate the soteriological function of the Spirit in the Fourth Gospel along the trajectory of W/wisdom.

In chapter 2, as a possible conceptual background for aspects of Johannine pneumatology, the representative Jewish wisdom writings are selected (Proverbs, Sirach, Wisdom of Solomon, Philo and some Qumran literature) and their nexus of Spirit-W/wisdom-'salvation' examined. From this investigation it is concluded that Wisdom is the source of life/salvation, in that Wisdom's revelatory teaching contains saving wisdom-knowledge-truth that leads to (eternal) life/salvation, and the Spirit is the agent of salvation, in that the Spirit mediates this life to people. It is suggested that sapiential Judaism understood

1 Cornelis Bennema, The Power of Saving Wisdom: An Investigation of Spirit and Wisdom in Relation to the Soteriology of the Fourth Gospel (Ph.D. thesis, London Bible College/Brunel University, 2001); supervisor: Prof. Max Turner. 
'salvation' as an intensification of that work of the Spirit that is already immanent to a person, namely, the mediation of life and wisdom. This saving work of the Spirit was sometimes/often experienced bringing new qualities of understanding, life and relationship with God. Hence, a model of salvation is proposed in terms of various degrees of intensity and/or quality of divine Spirit and W/wisdom. By virtue of their creation, people have Spirit, a certain measure of wisdom, and the cognitive ability to process wisdom (the 'mind'). 'Salvation', then, is a sufficient increase in measure and difference in quality of endowment of Spirit and W/wisdom. This model is explicitly present in Wisdom of Solomon and in Philo, and to a lesser extent in Qumran and Sirach.

Chapter 3 examines twenty-two Johannine soteriological themes, grouped in four thematic clusters: (i) the identity and mission of the Father and Son and their relationship; (ii) people's perception of and responses to Jesus; (iii) people in relationship with the Father and Son; (iv) discipleship. On this basis, an overall model of Johannine soteriology is developed that depicts the various activities of entering into and remaining in salvation, that holds together both the relational and cognitive aspects of salvation, and that assists in identifying the specific activities in which the Spirit is involved. The Spirit is active in/through Jesus' revelatory teaching and somehow mediates life to people. In fact, the Spirit seems to function as the facilitator of cognitive perception and understanding, which enables a person to make an adequate (i.e. authentic and sufficiently salvific) beliefresponse that results in entering into a life-giving relationship with the Father and Son. The Spirit is also expected to sustain the believer's saving relationship. Hence, salvation can be defined as being brought and kept in relationship with the Father and Son through the Spirit. Moreover, John seems to understand faith as a Spirit-informed cognitive belief-response to Jesus and his revelation, which is expressed in discipleship. However, some important questions still need to be answered. How does the Spirit enable a person to come from sensory to cognitive perception? How precisely does the Spirit mediate life?

Chapter 4 examines Jesus' revelatory encounters with Nicodemus, the Samaritan woman, and the Jews in John 6, and elucidates their respective metaphors-the 'birth of the Spirit', the offer of 'living water' and 'the bread of life' (in combination with 'the Spirit gives life'). According to John 3 and 6, Jesus brings down from heaven God's revelation, which contains saving wisdom and culminates in 
the cross. This revelation needs to be perceived cognitively in order to be life-giving. It is precisely the Spirit that facilitates this cognitive perception and understanding, which results in a saving relationship with the Father and Son through a birth of the Spirit. The basis for the Spirit's life-giving cognitive function is Jesus' word/teaching that contains saving wisdom, cleanses and leads to eternal life (Jn. 4 and 6). Moreover, John 1:32-34 and 3:34, alluding to Isaiah 11:2, depict the Messiah being endowed by the Spirit with wisdom, understanding, knowledge and power. Hence, the Spirit provides revelatory wisdom to both Jesus and other people. The revelatory wisdom provided to Jesus by the Spirit is the basis of/for his revelatory teaching that leads to life, and this wisdom (as the content of Jesus' life-giving teaching) becomes 'saving wisdom' mediated to people by the Spirit. This saving wisdom is the basis on which people can cognitively perceive and understand the significance of Jesus' revelatory teaching, which can subsequently lead to an adequate belief-response that brings one into a saving relationship with the Father and Son. Thus, the Spirit facilitates understanding and life in his function as a life-giving cognitive agent.

Chapter 5 argues that the Spirit as Paraclete is soteriologically necessary for several reasons. First, the intimate saving relationship between the believer and the Father and Son is realised and maintained by means of the Paraclete as the organ of communication and bond of union/friendship (e.g. 14:15-24; 15:13-15). Second, as the 'Spirit of T/truth', the Paraclete mediates saving truth to people in order to increase their cognitive perception of the Truth (=Jesus) so that they can make an (initial or continuous) adequate belief-response (15:26; 16:13). Third, as Teacher/Revealer, the Paraclete opens up Jesus' life-giving teaching and mediates its saving truth/wisdom to people $(14: 26 ; 16: 12-15)$. Fourth, as Advocate, the Paraclete's witness, mediated through the disciples' witness, is directed to the world to convict it, with salvation or judgement dependent on one's attitude towards this correlated witness $(15: 26-27 ; 16: 8-11)$. If we accept that as Teacher the Paraclete is also Advocate, then the following picture emerges. The Paraclete cannot prosecute the world directly because the latter cannot see or know him (14:17). Consequently, the Paraclete teaches the disciples the significance of Jesus' revelation to prepare their combined witness to the world. Thus, the Paraclete prosecutes the world indirectly through the disciples and their witness, in order to convict the world of its guilt so that some may accept this Paraclete-imbued witness. Hence, the 
Paraclete functions as a life-giving cognitive agent at two levels: at the level of the disciples/believers and at the level of the world.

The final chapter summarises the results of the study. It is argued that the soteriological function of the Spirit is twofold. First, the Spirit brings into being a saving relationship between the believer and the Father and Son, by mediating to people the saving wisdom present in Jesus' life-giving teaching. The Spirit thus enables the believer to come to an adequate understanding and belief-response. Second, the Spirit sustains this saving relationship through further mediation of wisdom that enables the believer to demonstrate discipleship as an ongoing belief-response. Hence, the Spirit accomplishes his soteriological role precisely in his function as a life-giving cognitive agent. Moreover, the Spirit is also an affective agent, in that the wisdom mediated by the Spirit is expected to affect people's moods, feelings, will, attitudes and motivations. This concept of the Spirit as a life-giving cognitive (and affective) agent is the most important continuity between the models of salvation in sapiential Judaism and in the Fourth Gospel. This study may affect, for example, our understanding of salvation. Salvation is not simply an intellectual adherence to a particular set of propositions, nor a superficial relationship with Jesus 'with no strings attached'. John advocates a relational cognitive belief, i.e. a personal relationship with and allegiance to Jesus (and the Father) that has a cognitive foundation provided by the Spirit. Finally, three areas for further research are recommended: Johannine soteriology (including our initial model of it), the concept of the Spirit as an affective agent, and Johannine ethics and epistemology. 